\title{
Efektivitas Sumber Pembelajaran Sejarah
}

\author{
Mohammad Namiraz Prananda, Sarkadi, Nurzengky Ibrahim \\ Universitas Negeri Jakarta \\ Aurumraz@gmail.com
}

\begin{abstract}
This study aims to describe the effectiveness of learning resources in history learning by using documentary films to foster interest in learning history and nationalism of students. This study uses descriptive qualitative methods. The time for this study began from March to July 2018 at SMAN 61 Jakarta and SMAN 103 Jakarta. Data collection techniques by observation, interviewing informants were students who took history learning with the documentary film media and key informants is teachers who used the documentary. This study describes some of the findings and discussion of the research, namely what the teacher's goal is to use the film documentary. how students' interest in learning after watching the film and the film can foster student nationalism. the goal of the teacher to use documentary films as a medium is to help students make it easier to absorb the lessons that teachers convey. In terms of interest, students are more interested in learning history and learning independently. The film effectively fosters student nationalism. Students better understand the meaning of Indonesian nationalism after doing the learning.
\end{abstract}

Keywords: Effectiveness, Media of Documentary Film, Interest and Nationalism

\begin{abstract}
Abstrak: Penelitian ini bertujuan untuk mendeskripsikan efektivitas sumber belajar pembelajaran sejarah dengan menggunakan film dokumenter untuk memupuk minat belajar sejarah dan nasionalisme siswa. Penelitian ini menggunakan metode deskriptif kualitati. Waktu penelitian ini dimulai dari maret sampai juli 2018. Di SMAN 61 Jakarta dan SMAN 103 Jakarta. Tehnik pengumpulan data dengan observasi, wawancara informan yaitu siswa yang mengikuti pembelajaran sejarah dengan media film dokumenter tersebut dan key informan, guru mata pelajaran yang menggunakan film dokumenter. Penelitian ini menjabarkan beberapa temuan dan pembahasan penelitian yaitu apa tujuan guru menggunakan film dokumenter tersebut, bagaimana minat belajar siswa setelah menonton film tersebut serta apakah film tersebut dapat memupuk nasionalisme siswa. Tujuan guru menggunakan film dokumenter sebagai media adalah untuk membantu siswa agar lebih mudah untuk menyerap pelajaran yang guru sampaikan. Untuk segi minat, siswa lebih tertarik belajar sejarah danbelajar secara mandiri. Film tersebut efektif memupuk nasionalisme siswa. siswa lebih mengerti makna dari nasionalisme Indonesia setelah melakukan pembelajaran tersebut.
\end{abstract}

Kata Kunci : Efektivitas, Media Film Dokumenter, Minat dan Nasionalisme

\section{PENDAHULUAN}

Pada era milenial dewasa ini, globalisasi adalah sebuah tantangan bagi setiap negara. Negara manapun dinilai tidak bisa mengabaikan arus 
globalisasi ini, pada hakikatnya globalisasi adalah arus perkembangan zaman dimana informasi di suatu negara atau daerah dapat dengan mudah diakses di belahan bumi lainnya. Menurut Anne Kreuger yang penulis kutip dari buku Martin Wolf, mendefinisikan globalisasi suatu fenomena dimana agen-agen ekonomi dibagian manapun di dunia jauh lebih terkena dampak peristiwa yang terjadi ditempat lain di dunia, dari pada sebelumnya (Wolf, 2007: 16).

Dapat dipahami bahwa globalisasi membuat kita mengikuti perkembangan disuatu daerah tertentu dan kita bisa merasakan dampak dari globalisasi di suatu daerah tertentu. Begitu bebasnya informasi yang didapatkan dari efek globalisasi juga menimbulkan hal buruk, tidak dapat kita pungkiri bahwa globalisasi membawa kita masuk kedalam arus budaya kultur modern. Sebenarnya bukan sebuah masalah masuknya kultur modern, bila kita dapat menyaring budaya yang baik dan tidak tentu globalisasi menjadi sangat baik.

Namun pada faktanya bahwa globalisasi mengikis nilai-nilai luhur budaya bangsa Indonesia. Contohnya bagaimana pemerintah dengan berbagai cara sebenarnya sudah mencoba menguatkan fondasi nasionalisme dengan melalui pendidikan, pemerintah berusaha memperkuat budaya dan nasionalisme peserta didiknya.

Bangsa ini adalah bangsa yang sangat plural, terlalu banyak suku bangsa dalam sebuah naungan negara kesatuan Indonesia ini. Oleh karena itu nasionalisme tanpa memandang perbedaan suku tersebut haruslah dikedepankan. Perbedaan tersebut dapat dikatakan sempat meruncing di beberapa daerah di Indonesia. Oleh karena itu pendidikan sangatlah penting untuk mengedukasi masyarakat akan pentingnya 
menjaga nilai budaya bangsa dan nasionalisme. Nasionalisme dapat dipupuk melalui pendidikan. Pendidikan sangat penting untuk menjamin perkembangan dan kelangsungan kehidupan suatu bangsa. Salah satu mata pelajaran yang dapat memperkokoh nasionalisme adalah mata pelajaran sejarah.

Namun pada fakta dilapangan gempuran arus globalisasi yang kuat, mulai mengikis nasionalisme peserta didik. Mereka lebih bangga dan lebih paham akan sejarah dari bangsa lain. Bagi penggemar kebudayaan Jepang misalnya, mereka paham atau bahkan cakap tentang budaya Jepang. Bagi penggemar budaya India, mereka mengerti makna dari kain sari yang merupakan pakaian khas wanita India. Begitu pun dengan budaya-budaya bangsa lainnya.

Minat belajar yang rendah justru harusnya membuat para guru kreatif dalam mengajar. Metode yang menarik tentu diperlukan oleh siswa agar mereka giat belajar untuk meningkatkan prestasi mereka. Metode yang inovatif perlu dikembangkan. Guru sebenarnya telah mencoba menerapkan beberapa metode dalam belajar mengajar, khususnya pelajaran sejarah. Metode konvensional seperti ceramah memang menjadi andalan guru sejarah dalam mengajar. Tidaklah salah memang mengingat dalam pelajaran sejarah ceramah berperan sangat penting dalam menyampaikan isi pokok bahasan. Itu karena sejarah berbeda dari pelajaran lainnya, khususnya ilmu alam. Oleh karena itu ceramah merupakan andalan bagi guru sejarah.

Penelitian ini difokuskan untuk mengetahui bagaimana efektivitas metode belajar sejarah yang lain yaitu film dokumenter untuk memupuk minat belajar siswa dan nilai nasionalisme. Dalam penelitian ini penulis 
ingin melihat minat belajar sejarah siswa dan nasionalisme siswa dengan mencoba mengajarkan sejarah berbasis penayangan film dokumenter pra dan kemerdekaan Indonesia. Film dokumenter yang guru gunakan adalah film dokumenter tentang peperangan sebelum dan sesudah kemerdekaan Indonesia.

Kata efektif berasal dari bahasa Inggris yaitu effective yang di definisikan "producing a desired or intended result" yang juga dapat diartikan berarti berhasil atau sesuatu yang dilakukan berhasil dengan baik (Tika, 2006:129). Soekanto juga mengatakan bahwa Efektifitas merupakan taraf sejauh mana seseorang atau sekelompok untuk mencapai tujuannya (Soekamto,1985). Dan menurut William J. Reddin yang mengatakan bahwa Efektifitas adalah suatu tindakan untuk mengoptimalkan sumber pendidikan, memperoleh hasil pendidikan dan meningkatkan pendidikan (Pidarta,1989: 24).

Beberapa teori diatas adalah teori secara umum atau gambaran umum mengenai apa yang dimaksud dengan efektivitas. Namun bila efektivitas diukur dari perspektif pendidikan kilat atau diklat, maka berbeda pula pengertiannya. Efektif tidaknya pelatihan dilihat dari dampak pelatihan bagi organisasi dalam mencapai tujuan yang menjadi target organisasi tersebut.

Berdasarkan beberapa pengertian tentang efektivitas di atas, maka dapat disimpulkan bahwa efektivitas adalah sejauh mana tujuan tersebut tercapai dan berhasil dengan baik serta sejauh mana keberhasilannya dapat diukur dari dapak yang ditimbulkan dari suatu pelatihan tersebut. Selain itu teori lain yang digunakan adalah tentang media. Pengertian media beragam, sesuai dengan cara pandang ahli, Sadiman yang peneliti 
kutip dari Musfiqon (Musfiqon, 2012:26). Media adalah perantara atau pengantar pesan dari pengirim pesan. Kita pahami bahwa media adalah pengantar pesan dalam hal ini untuk pendidikan, bila begitu kita artikan media adalah sebagai media penyampai seuatu materi pendidikan kepada murid.

Robert Hanrick dan kawan-kawan mengatakan media adalah saluran komunkasi termasuk film, televisi, diagram, materi tercetak, komputer dan instruktur (Musfiqon, 2012: 27). Berdasarkan teori tersebut mengatakan bahwa televisi dan film merupakan media. Jika kita berbicara tentang film maka kita tentu berbicara tentang film sebagai media pembelajaran.

Bila dirangkum maka film dokumenter sebagai media pembelajaran adalah visualisasi yang mencakup beberapa nilai khususnya nilai pelajaran yang ingin disampaikan, dalam hal ini dikususkan tentang sejarah bangsa Indonesia Pra dan Kemerdekaan Indonesia. dalam film tersebut harus merepresentasikan pembelajaran sejarah yang dapat peserta didik telaah dengan mudah.

Menurut Soejanto Sandjaja secara umum minat dapat diartikan sebagai suatu kecenderungan yang menyebabkan seseorang berusaha untuk mencari ataupun mencoba aktivitas-aktivitas dalam bidang tertentu (Sandjaja. 2004 : 2-3). Slameto mengatakan Minat adalah rasa lebih suka dan rasa ketertarikan pada suatu hal atau aktivitas, tanpa ada yang menyuruh. Menurut Slameto (2010:180) minat merupakan rasa untuk melakukan sesuatu yang diinginkan tanpa adanya paksanaa atau intervensi dari puhak lain. 
Untuk mendefinisikan minat berdasarkan substansi berminat maka artinya adalah menaruh hati atau memperhatikan atau menginginkan. Definisi dari kata minat tidaklah mudah untuk ditemukan refrensinya. Setiap ahli mendifinisikan kata minat berbeda-beda, namun kita dapat simpulkan bahwa minat adalah sesuatu ketertarikan akan sesuatu. Minat belajar pada siswa juga muncul karena adanya motivasi dari seorang guru. Guru yang berminat tinggi dan antusias akan menghasilkan muridmurid yang berminat tinggi dan antusias pula. Motivasi penting bagi siswa dalam mencapai tujuan pembelajaran. Motivasi dapat diartikan sebagai daya upaya yang mendorong seseorang untuk melakukan sesuatu. (Suprijono,dkk., 2016).

Berkat dorongan orang lain, murid akan selalu berusaha lebih giat karena minat belajarnya menjadi lebih besar. Selain keantusiasan guru, teknik dan proses pembelajaran yang bermacam-macam dan media pembelajaran yang bervariatif juga sangat efektif untuk memelihara minat murid (Setiawati, dkk., 2014).

Lucy mendefinisikan minat belajar siswa terhadap pembelajaran berbanding lurus dengan prestasi dan hasil belajar (Lucy dan Julius, 2012:160). Dapat diartikan bahwa untuk mengukur minat belajar peserta didik dapat diukur dari prestasinya dalam suatu pembelajaran tertentu. Bila kita menyimpulkan berdasarkan teori minat diatas maka dapat kita artikan minat adalah sebagai kegemaran seseorang terhadap sesuatu yang dapat ditumbuhkan atau di kembangkan. Bila kita mengukur minat dari segitu pembelajaran maka kita dapat mengukur tingkat minat seseorang dari prestasi belajarnya. 
Nasionalisme adalah sebuah paham tergolong baru dalam perbendaharaan kata. Jika ditinjau dari segi konsep pun nasionalisme baru didengungkan pada abad 20-an. Nasionalisme yang merebak di penjuru dunia karena bangsa barat yang melakukan kolonialisme di berbagai belahan dunia. Era kolonialisme adalah sebuah era yang dapat disimpulkan sebagai awal dari nasionalisme. Kolonialisme yang dilakukan oleh bangsa barat merupakan suatu titik awal timbulnya rasa cinta terhadap tanah air mereka. Bangsa barat yang melakukan penjajahan khususnya di benua asia merubah sudut pandang suatu bangsa. Menurut Sartono Kartodirdjo bahwa banyak definisi nation telah ditawarkan oleh para ahli, dari Renan sampai Kohn, Hayes atau Hertz, kebanyakan menitikberatkan salah satu aspek, antara lain : aspek politik, sosial, ekonomi, kultural, dan psikologis. Berdasarkan beberapa hal tersebut Sartono Kartodirjo (Kartodirjo,1999:1) mengemukakan rumusan definisi nasion yang menunjuk pada suatu komunitas kesatuan kehidupan bersama yang mencakup berbagai unsur yang berbeda dalam aspek etnik, kelas atau golongan sosial, aliran kepercayaan, kebudayaan linguistik, dan lain sebagainya. Kesemuanya terintegrasikan dalam perkembangan historis sebagai kesatuan sistem politik berdasarkan solidaritas yang topang oleh kemauan politik bersama. Prinsip nasionalisme yang Indonesia anut umumnya mencakup tigal hal, antara lain: Persatuan, pembebasan dan patriotisme (Musa, 2010:11).

Dalam penelitian ini bertujuan untuk untuk memeperoleh data dan informasi yang mendalam tentang bagaimana pembelajaran sejarah dengan menggunakan film dokumenter kemerdekaan mempengaruhi minat belajar sejarah dan nasionalisme siswa. Untuk mengetahui nilai 
pelajaran sejarah sesudah pelaksanaan pembelajaran pemutaran film dokumenter pra dan kemerdekaan.. Sikap nasionalisme yang ditunjukan oleh siswa setelah mengikuti pembelajaran sejarah berbasis film dokumenter pra dan kemerdekaan.

\section{METODE}

Metode yang digunakan dalam penelitian ini adalah kualitatif. Metode kualitatif adalah metode penelitian yang dirancang untuk memperoleh informasi tentang suatu gejala pada saat penelitian dilakukan yang bertujuan untuk menjabarkan variabel atau kondisi apa yang ada dalam suatu situasi dan tidak melakukan pengujuan hipotesis (Sugiono, 2009: 225). Penelitian ini dilakukan di SMAN 61 Jakarta dan SMAN 103 Jakarta. Dimulai sejak april-juni 2018. Penelitian kualitatif ini menggunakan metode observasi, wawancara, dokumentasi. Sumber data utama dalam penelitian kualitatif ialah kata-kata, dan tindakan, selebihnya adalah data tambahan seperti dokumen dan lain-lain. Penelitian kualitatif ini menggunakan metode observasi, wawancara, dokumentasi. Aktivitas dalam analisis data, yaitu data reduction, data display dan conclusion drawing/verification.

\section{HASIL}

Ekfektivitas guru menggunakan film dokumenter untuk pembelajaran yang efektif dan untuk memupuk minat belajar dan memotivasi siswa

Tujuan digunakannya film dokumenter sebagai untuk media belajar. Guru menggunakan film juga sebagai alat pendukung dalam mempermudah guru dalam menyampaikan materi yang guru ajakarkan, ini didukung oleh wawancara dengan Ibu Dwi Kus. Ibu Dwi menggunakan film dokumenter sebagai media pembelajaran agar materi 
pembelajaran mengena kepada siswa. ibu Dwi ingin menyampaikan peristiwa masa lampau dengan kejadian yang sebenarnya tidak dengan teori. Agar anak-anak lebih tahu kejadian yang sebenarnya. Key informan lainnya tujuannya penggunaan sesuai dengan tema. Bila temanya berhubungan dengan perjuangan, Ibu Maria akan menggunakan media film dokumenter supaya anak lebih mengetahui perjuangan bangsa Indonesia serta lebih menjiawi kepahlawanan. Selain itu digunakannya film dokumenter untuk memupuk minat siswa belajar sejarah lebih baik.

Berdasarkan dari pendapat key informan bernama ibu Maria Prasekti tersebut, dapat kita katakan bahwa penggunaan film dokumenter sebagai sumber belajar sejarah bertujuan untuk membantu guru dalam memberikan materi belajar sejarah serta agar siswa lebih menjiwai dan menyerap materi lebih baik dengan gambaran yang jelas, dan untuk siswa lebih meminati pelajaran sejarah lebih baik.

\section{Pemupukan Nilai Nasionalisme}

Tujuan digunakannya film dokumenter oleh guru adalah untuk memotivasi siswa agar lebih minat belajar sejarah dan lebih memahami Prinsip nasionalisme yang Indonesia anut. Prinsip nasionalisme mencakup tiga hal, antara lain : (1) Persatuan; (2) Pembebasan; (3) Patriotisme.

Nasionalisme adalah kesetiaan individu terhadap bangsanya yang dijiwai dengan loyalitas terhadap bangsanya, serta melindungi segenap bangsanya. Bila kita simpulkan makna nasionalisme Indonesia adalah rasa bersatu tanpa memandang suku dan ras serta menjiwai sila-sila Pancasila yang mempunyai ciri sebagai berikut : 1) bangga akan rasa persatuan yang kuat; 2) rasa untuk menghargai pemdapat orang lain, rasa 
bebas dari segala bentuk penjajahan dan rasa bebas untuk belajar setinggitingginya untuk kehormatan dirinya dan bangsanya; 3) rasa akan mencintai negeri dan rasa ingin membela negeri dalam berbagai hal khususnya dalam pendidikan.

\section{PEMBAHASAN}

Efektivitas Penggunaan Media Film Dokumenter Sebagai Sumber Belajar Sejarah

Setiap pembelajaran yang diberikan tentulah harus efektif. Namun untuk mencapai kata pembelajaran yang efektif tentu memenuhi beberapa syarat. Henry Simamora mengatakan evektivitas diklat dapat dilihat dari reaksi perasaan partisipan terhadap program. Belajar pengetahuan, keahlian, dan sikap-sikap yang diperoleh sebagai hasil dari pelatihan. Perilaku perubahan yang terjadi pada pekerjaan sebagai akibat dari pekerjaan (Basri dan Rusdiana, 2006: 114). Kemudian ketepatgunaan penggunaan media film dokumenter untuk pembelajaran yang efektif juga dikemukakan oleh Expert. Menurut pendapat Expert Manfaat atau nilai gunanya lebih besar dibandingkan siswa hanya mendengarkan saja apa yang diceritakan oleh guru atau siswa hanya membaca buku teks saja pada materi yang relevan.

\section{Memupuk Minat Belajar Sejarah Siswa}

Meningkatnya minat seseorang terhadap sesuatu dipengaruhi oleh beberapa faktor seperti, sesuatu yang baru, kompleksitas, ketidakmengertian dan pertentangan. Dengan penggunaan film dokumenter tersebut siswa yang sebelumnya tahu sejarah karena diwajibkan untuk belajar sejarah, ingin menjadi lebih tahu tentang sejarah. Itu dibuktikan dengan hasil wawancara berikut untuk 
mendukung teori tersebut. Berdasarkan wawancara dengan Informan bernama Damarhati, dengan film cerita tentang tokoh jadi ingin lebih tahu, browsing di Internet tokoh tersebut. Selain itu untuk menilai bagaimana peninglatan minat belajar dapat diukur berdasarkan hasil belajar. Dapat diartikan bahwa hasil belajar dapat dijadikan tolak ukur untuk mengetahui seberapa efektifnya film tersebut meningkatkan minat belajar siswa.

Peneliti tidak dapat mengurai secara jelas tentang peningkatan score belajar siswa terkait dengan kerahasiaan nilai sekolah. Peneliti hanya menjabarkan secara konteks bahwa setelah mengikuti pembelajaran dengan mediaa film dokumenter score belajar siswa meningkat walaupun tidak secara drastis karena sebelumnyapun nilai mereka dapat dikatakan cukup baik.

\section{Motivasi Belajar Lanjutan}

Selain itu pada penelitian ini, peneliti juga mengemukakan tentang bagaimana film dokumenter tersebut memotivasi siswa untuk belajar dan ingin tahu sejarah lebih jauh. Berikut adalah transkrip wawancara dengan informan bernama Shrie, apakah film dokumenter dapat memotivasi nelajar sejarah lebih jauh. Berdasarkan wawancara pasti karena kan misalnya kuliah harus mempelajari sejarah-sejarah yang terjadi. Tapi secara pribadi dia mengatakan sejarah itu asik dan menyenangkan kalau gurunya berpengaruh terhadap cara dia mengajar kepada muridmuridnya.

Menurutnya film tersebut memotivasi untuk belajar sejarah. Namun menurutnya pelajaran tersebut lebih tergantung kepada gurunya. Pendapat lain dikemukakan oleh infroman bernama Josua mengatakan 
bahwa film dokumenter tersebut membuat dia ingin memcari tahu tentang sejarah lebih jauh. Film dokumenter tersebut membuat dia penasaran tentang materi pelajarn sejarah tersebut dan ingin mencari tahu tentang pelajaran sejarah tersebut.

Film dokumenter membuat motivasi siswa untuk ingin lebih mengerti tentang sejarah. Dengan penayangan film dokumenter sebagai sumber belajar sejarah tersebut ternyata dapat memotivasi siswa dan motivasinya untuk ingin lebuh tahu tentang sejarah. Pendapat lain dikemukakan oleh siswa lainnya, Ia mengatakan untuk belajar lebih dalam tentang pelajaran sejarah mungkin tidak. Namun menurutnya untuk memotivasi siswa belajar lebih giat iya. Karena metode belajar yang digunakan menurutnya cukup menyenangkan dan tentu dengan cara yang tersebut siswa lebih semangat untuk belajar.

Pemupukan Nilai Nasionalisme Pada Siswa Setelah Mengikuti Pembelajaran Sejarah Berbasis Pemutaran Film Dokumenter Pra Kemerdekaan

Selain penelitian tentang minat belajar sejarah siswa dengan film dokumenter sebagai sumber belajar sejarah, peneliti juga meneliti bagaimana film dokumenter memupuk nasionalisme siswa. peneliti mewawancarai informan dan key informan tentang pemupukan nasionalisme pada siswa dengan menggunakan film dokumenter tersebut. Pada wawancara dengan informan kunci, ibu Dwi selaku guru mata pelajaran sejarah wajib di SMAN 103 mengatakan menurut sudah menghargai nilai-nilai Pancasila dan mengamalkan. Dalam pandangan ibu Dwi para siswa telah menghargai dan mengamalkan nilai Pancasila.

Kemudian key informan lainnya Ibu Asfiyah, Menurut Ibu Asfiyah seharusnya para siswa menginternalisasikan perjuangan kemerdekaan. 
Dengan meninternalisasikan perjuangan bangsa maka siswa dinilai telah mengamalkan nilai dari Pancasila. Pendapat lain tentang pemupukan nilai nasionalisme di kemukakan oleh Ibu Maria prasekti, beliau mengatakan dalam film anak-anak melihat langsung bagaimana fakta sejarah seperti apa. Bagaimana para pahlawan itu pengorbanan jiwa raganya. Dalam film itu jelas dan sangat menimbulkan jiwa anak-anak. Dapat diartikan bahwa dengan menonton film tersebut siswa dapat melihat secara langsung bagaimana pengorbanan pahlawan dalam memedekakan bangsa ini. Tentu dengan contoh kepahlawanan yang mereka saksikan, mereka dapat mengerti tentang nilai Pancasila lebih baik. Nilai dari nasionalisme tentu akan mereka sedikit mengerti dengan tayangan tersebut.

Selain itu penelitian ini juga membahas tentang nilai apa saja yang telah siswa terapkan berdasarkan film dokumenter tersebut. Berdasarkan wawancara dengan para Key Informan dan Informan tentang apa saja yang telah mereka terapkan atau nilai apa saja yang telah mereka terapkan dari film dokumenter tersebut.

Menurut Ibu Dwi K. ketika peneliti mewawancarai tentang nilai apa saja yang siswa telah terapkan dari menonton film tersebut beliau menjelaskan ada, paling tidak kerjasama dan kekompakannya. Menurut ibu Dwi kerjasama dan kekompakan telah mereka terapkan setelah pembelajaran dengan film dokumenter tersebut. Menurutnya siswa telah mencontohkan nilai kerja sama dan kompak ketika sedang belajar di dalam kelas.

Sedangkan menurut ibu Maria Prasekti, kebersamaan dan cinta tanah air telah siswa terapkan namun tidak semua siswa telah menerapkannya. Peneliti mengerti tentu tidak semua akan bisa menerapkan atau paling 
tidak mengerti tentang nilai di film dokumenter tersebut.Penjabaran lebih lanjut temuan penelitian tentang nasionalisme akan di urai lebih lanjut pada sub fokus yang lebih rinci lagi tentang nilai nasionalisme berikut.

\section{Pemahaman Nilai Persatuan}

Dan untuk mengetahui apakah para siswa telah mengerti nilai persatuan tersebut peneliti melakukan wawancara dengan beberapa informan, informan bernama Reza, dia mengatakan film dokumenter tersebut memberikan nilai tentang persatuan sebagai bangsa. Ia juga mengatakan dengan nilai persatuan tersebut dapat membantu bangsa Indonesia dalam mengatasi berbagai masalah pada bangsa ini. Bangsa Indonesia adalah bangsa yang beraneka ragam suku, bangsa, budaya dan agama. Tentunya dengan nilai persatuan perbedaan tersebut dapat bangsa ini atasi dengan mudah.

Wawancara informan lainnya yaitu dengan Tarisa, ia mengatakan untuk mencapai suatu kemerdekaan butuh kebersamaan dalam satu bangsa itu. Kemerdekaan sebuah bangsa menurutnya tidaklah bisa dilakukan dengan sendirian. Mencapai sebuah kemerdekaan diperlukannya sebuah kebersamaan dalam sebuah bangsa.

Pendapat lainnya dari Khaira, ia mengatakan contohnya semangat para pejuang dalam mempertahankan kemerdekaan, persatuan dan penyampaian berbagai aspirasi. Menurut Khaira, contoh nilai persatuan adalah bagaimana semangat para pejuang dalam mempertahankan kemerdekaan bangsa ini. Ia juga menilai nilai persatuan lainnya adalah penyampaian berbagai aspirasi. Mungkin ia menganggap bahwa asprasi atau ide pemikiran adalah bagian dari nilai persatuan sebagai bangsa. Karena sebuah bangsa tidak dibangun berdasarkan pemikiran satu tokoh 
bangsa saja. Bila tadi dijelaskan apa pendapat informan tentang nilai persatuan maka pada bagian ini peneliti menjabarkan apakah para siswa telah memahami sikap seperti apa yang mencerminkan nilai dari persatuan tersebut.

\section{Pemahaman Nilai Pembebasan}

Pemahaman nasionalisme selanjutnya adalah tentang pemahaman nilai pembebasan. Peneliti telah melakukan wawancara dengan beberapa informan tentang makna dan nilai dari pembebasan. Berikut adalah sintesis wawancara dari beberapa informan tersebut. Khaira mengatakan, arti dan makna pembebasan dari film dokumenter tersebut adalah dimana adanya rasa kesadaran rakyat Indonesia untuk merdeka, terlepas dari segala belenggu penjajahan. Penjajahan yang mengakibatkan Indonesia menjadi negara yang mengalami kemunduran dari segala aspek . Terutama saat masa penjajahan Jepang yang sangat amat kejam, negara ini diperas habis habisan hanya untuk kejayaan Nippon sedangkan rakyat Indonesia sangat amat menderita. Lalu munculah berbagai pemberontakan dari rakyat Indonesia yang menyadari bahwa negara Indonesia haruslah berdiri sendiri tanpa harus dipimpin oleh negara lain.

Dalam film dokumenter tersebut menurutnya menjelaskan bahwa bangsa Indonesia ingin merdeka. Perbudakan khususnya pada masa Jepang sangat kejam. Sumber daya alam dan manusia digunakan untuk kejayaan Jepang saja. Dari situlah menurutnya muncul pemberontakan yang menginginkan bangsa ini merdeka agar terbebas dari perbudakan tersebut. Pendapat lainnya juga dikemukakan oleh informan bernama Alle beranggapan makna dari nilai pembebasan adalah tekad keberanian 
dan ketangguhan untuk memerdekaan bangsa Indonesia. dengan nilai yang ia jabarkan bangsa Indonesia telah terbebas dari penjajahan.

\section{Pemahaman Nilai Patriotisme}

Nilai nasionalisme lainnya adalah nilai patriotisme. Jiwa patriotisme adalah nilai yang terpenting untuk mempupuk nasionalisme. Film dokumen tersebut tentu menampilkan nilai patriotisme. Bagaimana siswa menyerap dan menelaah dengan baik nilai patriotis dalam film tersebut, berikut adalah pemahaman tentang makna patriotisme dari siswa yaitu sikap rela berkorban untuk negara, misalnya kita disuruh untuk ikut bela negara kita bela negara.

Beberapa negara memang menerapkan kebijakan bela negara, yaitu wajib militer. Namun tentu kebijakan wajib militer tersebut dipikirkan dengan matang. Indonesia memang tidak pernah menjalankan bela negara berupa wajib militer. Namun undang-undang Indonesia mewajibkan bela negara ketika Indonesia membutuhkannya. Hal itulah yang menurut Reza merupakan makna dari nilai patriotisme. Rela berkorban untuk bangsa adalah hal yang mencerminkan nilai patriotisme menurutnya.

Pendapat lainnya tentang patriotisme dijelaskan oleh Tarisa, Jawaban Tarisa tentang makna Patriotisme lebih kepada jiwa patriotisme dilingkungan sekolah. Mengikuti upacara dan menyanikan lagu Indonesia raya dengan khidmat maka itu telah mencerminkan patriotisme. Jawaban lainnya Pandangan Alle tentang makna patriotisme adalah mementingkan kepentingan bangsa terlebih dahulu. Alle juga mengatakan telah mencontohkan nilai dari patriotisme tersebut seperti mementingkan kepentingan bersama dan menaati hukum yang ada. Jawaban yang sangat 
baik dikemukakan oleh Alle tentang makna dari patriotisme yang dapat Alle pahami dari film dokumenter tersebut.

\section{KESIMPULAN}

Pembelajaran sejarah dengan menggunakan media film dokumenter sebagai sumber belajar untuk meningkatkan minat belajar sejarah siswa cukup efektif. Peneliti dapat menyimpulkan demikian karena berdasarkan teori yang peneliti gunakan yaitu bahwa minat sebanding lurus dengan peningkatan hasil belajar telah peneliti buktikan. Pemupukan nasionalisme siswa dengan film dokumenter diakatan efektif. Berdasarkan penelitian siswa mengerti nilai dan makna nasionalisme dengan menonton film dokumenter tersebut karena sesuai dengan teori yang peneliti gunakan dan didukung oleh pendapat ahli tentang bagaimana audiovisual memacu siswa untuk menyerap pelajaran lebih baik. Disarankan pihak sekolah untuk lebih mendukung guru mata pelajaran dan membuat film dokumenter secara mandiri agar pembelajaran dapat lebih efektif. Dan guru mata pelajaran sejarah wajib peneliti sarankan untuk menampilkan film dokumenter yang lebih beragam dengan perangkat keras yang lebih mendukung.

Pada penelitian tentang pemupukan nasionalisme siswa, peneliti telah menyimpulkan bahwa film dokumenter dikatakan efektif memupuk nasionalisme siswa dengan wawancara informan, teori dan pendapat ahli. Berdasarkan hasil penelitian dan dikaji dengan teori nasionalisme yang peneliti gunakan. Dapat dikatakan film dokumenter tersebut memupuk nasionalisme siswa, karena siswa umumnya mengerti makna dari nilai persatuan, pembebasan,dan patriotisme dari film tersebut. Serta 
didukung dengan pendapat ahli bahwa film dokumenter tersebut membantu siswa lebih memahami makna nasionalisme tersebut.

\section{DAFTAR PUSTAKA}

[1] Basri, Hasan., dan Rusdiana. (2006). Manajemen Pendidikan $\mathcal{E}$ Pelatihan. Jakarta: Bina Aksara.

[2] Kartodirjo, Sartono. (1999). Nasionalisme, Lampau dan kini, dalam bingkau dinamika Nasionalisme Indonesia. Salatiga : Yayasan Bina Darma.

[3] Lucy, Bunda dan Ade Julius, (2012). Dahsyatnya Brain Smart Teaching. Jakarta: Penebar Swadaya Group.

[4] Musa, Ali Maksur. (2010). Nasionalisme Di persimpangan. Jakarta: Erlangga.

[5] Musfiqon. (2012). Pengembangan Media dan Sumber Pembelajaran. Jakarta : Prestasi Pustaka.

[6] Pidarta, Made. (1989). Manajemen Pendidikan. Jakarta: Bina Aksara.

[7] Sandjaja, Soejanto. (2004). Pengaruh Keterlibatan Orang Tua Terhadap Minat Membaca Anak Ditinjau dari Pendekatan Stres Lingkungan.

[8] Setiawati,Wakidi., dan Yusina Sri Ekwandari. Minat Belajar Sejarah Siswa Menggunakan Model Pembelajaran Koorporatif Tipe Think Talk Write. Jurnal Pendidikan dan Penelitian Sejarah. Vol : 2 No.4 Agustus 2014. Jurnal Ilmiah.

[9] Slameto. (2010). Belajar dan Faktor-Faktor yang Mempengaruhinya. Jakarta: Bina Aksara.

[10] Soekamto, Soerjono. (1985). Kamus Lengkap Sosiologi. Jakarta: Rajawali Press,.

[11] Sugiono. (2009). Metodologi Penelitian Kuantitatif Kualitatif dan R E D. Bandung: PT. Alfabeta.

[12] Suprijono, Agus. Sugeng Harianto, Ngunsiati, Sri Lestari, Restu Kemala. Penciptaan Iklim Pembelajaran Sejarah Yang Menyenangkan Melalui Snowball Drilling Method. Jurnal Ilmu Pendidikan. Vol : 14 No : 2 Febuari 2016.

[13] Tika, Moh. Pabundu. (2006). Budaya Organisasi dan Peningkatan Kinerja Perusahaan, Jakarta: Bumi Aksara.

[14] Wolf, Martin. (2007). Globalisasi Jalan Menuju Kesejahteraan. Jakarta: Freedom institute. 